\title{
DMAH tedavisi altında tekrarlayan derin ven trombozu
}

\author{
Recurrent deep vein thrombosis under LMWH treatment
}

Mehmet Kılınç, Mehmet Koray Adalı

Gönderilme tarihi:09.12.2020

Kabul tarihi:16.02.2021

Öz

Derin ven trombozu (DVT), alt veya üst ekstremite derin venlerinin trombozisi olarak tanımlanabilir. Tanı da ilk basamak renkli doppler ultrasonografi (DUSG) yer almaktadır. Tedavinin temelini antikoagülasyon oluşturmaktadır. Vakamız postpartum dönemde olan, ailesinde venöz tromboemboli öyküsü olan tekrarlayan DVT atakları olan kadın hastadır. Bu vakada tedavi edici dozlarda düşük molekül ağırlıklı heparin (DMAH) almasına rağmen tekrarlayan venöz tromboemboli (VTE) atakları olmuştur. Trombofili hastalarında gebelik ve loğusalık döneminde, tekrarlayan VTE'lerin önlenmesi için anti-Xa düzeylerine göre DMAH doz ayarı yapılması düşünülmelidir.

Anahtar kelimeler: Derin ven trombozu, DMAH, anti-Xa.

Kılınç M, Adalı MK. DMAH tedavisi altında tekrarlayan derin ven trombozu. Pam Tıp Derg 2021;14:514-517.

\begin{abstract}
Deep venous thromobosis (DVT) affects veins of the lower or upper extremities. The color doppler ultrasonography examination is at the first step of the diagnostic process. The basis of treatment is anticoagulation. The current case is a female patient with recurrent DVT attacks, in the postpartum period, with a family history of venous thromboembolism. In this case, recurrent attacks of venous thromboembolism (VTE) occurred despite receiving therapeutic doses of Low Molecular Weight Heparin (LMWH). In pregnant and puerperal patients with thrombophilia, dose adjustment should be considered according to anti-Xa levels in order to prevent recurrent VTEs during LMWH use.
\end{abstract}

Key words: Deep vein thrombosis, LMWH, anti-Xa.

Kilinc M, Adali MK. Recurrent deep vein thrombosis under LMWH treatment. Pam Med J 2021;14:514-517.

\section{Giriş}

Derin ven trombozu (DVT), venöz sistemin herhangi bir yerinde görülebilen sistemik bir hastalıktır. DVT, alt veya üst ekstremite derin venlerinin trombozisi olarak tanımlanabilir. DVT \%90 oranında alt ekstremite venöz sisteminde ortaya çıkmaktadır [1-3]. Üst ekstremitelerin venöz oklüzyonu oldukça nadirdir ve tüm vücut DVT'lerinin yaklaşık \%4'ünü oluşturur [4]. Yaş, immobilizasyon, oral kontraseptif kullanımı, hamilelik, cinsiyet, cerrahi, kanser ve travmalar önemli risk faktörleridir. Hastalığın akut döneminde ağrı, ödem ve kızarıklık gibi semptomlar görülebilir. Tanı da ilk basamak renkli doppler ultrasonografi (DUSG) incelemesi yer almaktadır. Tedavinin temelini antikoagülasyon oluşturmaktadır.

\section{Olgu sunumu}

19 yaşında, ev hanımı, ek hastalığı olmayan kadın hasta, doğum sonrası birinci ayda sol alt ekstremitede şişlik ve ağrı şikayeti ile hastanemizin acil servisine başvurdu. Sol ekstremitede şişlik, hassasiyet ve Isı artışı bulguları mevcuttu. Başvuru muayenesinde vitallari stabil, tam kan sayımı ve rutin biyokimyasal parametreleri normaldi. Akciğer grafisinde özellik saptanmadı. Klinik şüphe sonrası yapılan alt ekstremite venöz DUSG incelemede sol external iliac ven, ana femoral ve yüzeyel femoral ven, popliteal vende akım

Mehmet Kılınç, Uzm. Dr. Turgutlu Devlet Hastanesi, Kardiyoloji, Manisa, Türkiye, e-posta: klncmehmet@hotmail.com (https://orcid.org/0000-00027410-2101) (Sorumlu Yazar)

Mehmet Koray Adalı, Dr. Öğr. Üye. Pamukkale Üniversitesi Tıp Fakültesi Kardiyoloji Anabilim Dalı, Denizli, Türkiye, e-posta: korayadali@gmail.com (https://orcid.org/0000-0002-0054-6252) 
geçişine izin vermeyen trombüs ve ayrıca vena safena manga proksimal kesimde trombüs saptandı. Hastanın aile öyküsüsü sorgulandığında baba, kardeş ve halada DVT öyküsü olduğu belirlendi. Toraks bilgisayarlı tomografi anjiografisinde pulmoner tromboemboli saptanmadı. Hastaya KVC tarafından DVT ye yönelik başarılı trombektomi ve balon uygulaması yapıldı. İşlem sonrası herhangi bir komplikasyon gelişmedi. Trombofili paneli için ileri merkeze yönlendirildi. Hasta düşük molekül ağırlıklı heparin (DMAH), günde iki kez $1 \mathrm{mg} / \mathrm{kg}$ dozda enoksaparin ile taburcu edildi. Hasta taburculuğundan bir hafta sonra, bu sefer sağ bacakta şişlik ve ağrı şikâyeti ile hastanemize başvurdu. Muayenesinde sağ bacak şiş ve gergindi. Sağ alt ekstremite venöz DUSG'de trombüs izlendi. Hasta periferik anjioya alınarak sağ ekstremite DVT mekanik trombektomi ile giderildi (Resim 1). Hasta kiloya göre ayarlanmış dozda bemiparin 7500 IU 1x1 ile taburcu edildi. Takiplerinde bir ay boyunca herhangi bir olay yaşamayan, ilacını düzenli olarak kullanmaya devam eden hasta, bir ay sonra sağ kolda şişlik şikâyeti ile hastaneye başvurdu. Sağ üst ekstremite venöz DUSG incelemede brakial, bazilik ve sefalik venlerin duvar kalınlıkları artmış ve lümen içinde akıma izin vermeyen trombüs saptandı. Olguya tedavi dozunda DMAH ve eş zamanlı oral varfarin 5 mg/gün başlandı. International normalized ratio (INR) değeri 2'nin üzerine çıktıktan sonra DMAH tedavisi kesilen olgu şikâyetlerinin gerilemesi ile taburcu edildi. Kontrol üst ekstremite venöz doppler ultrasonografi tetkikinde aksiler, brakial ve distal derin venöz sistemde; yüzeyel sefalik ve bazilik venlerde trombüs lehine bulgu saptanmadı; akım mevcuttu. Hasta INR düzeyi 3-3,5 olacak şekilde 5 aydır olaysız takip edilmektedir.
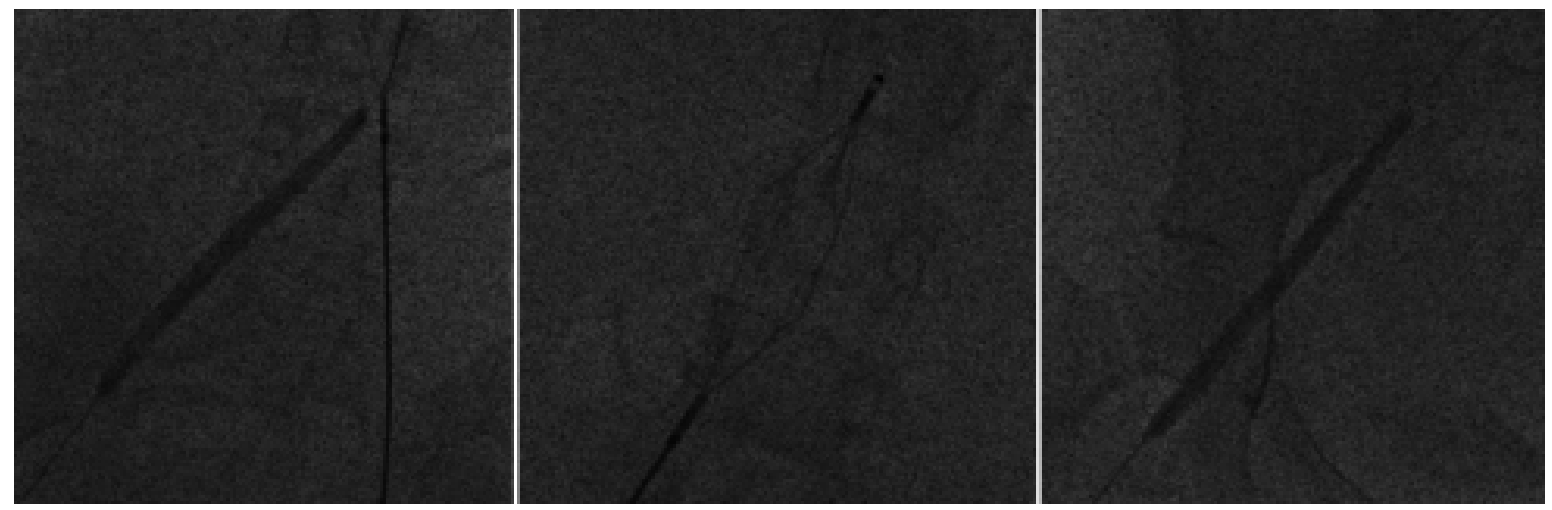

Resim 1. Balon dilatasyon ve geçici filtre

\section{Tartışma}

Gebelik ve loğusalıkta venöz tromboemboli (VTE) görülme sıklığı artmıştır (tüm gebeliklerin yaklaşık \%0,05-0,2'si) [5-9]. Akciğer embolisi ve derin ven trombozunu içeren VTE gebelikle ilişkili morbidite ve mortalitenin önemli bir nedenidir. Doğum sonrası erken dönemde VTE riski, özellikle sezaryenle doğum sonrasında en yüksek düzeyde olup doğum sonrası 6 . haftadan sonra gebe olmayan kadınlardaki düzeye inmektedir $[5,6]$.

Gebelikte ve loğusalıkta VTE için en önemli risk faktörleri önceden geçirilmiş idiyopatik DVT veya akciğer embolisi ve trombofililerdir (Tablo1) [10]. VTE'lerin \%15-25'i yinelenen olgulardır. Gebelik sırasında bir trombotik olayın geliştiği kadınların yarısında ya bir trombofilik bozukluk ya da önceden geçirilmiş idiyopatik VTE mevcuttur. Bu nedenle bireysel hastada, risk değerlendirmesi ve koruyucu stratejilerin seçilmesi için risk faktörlerinin tanımlanması önemlidir. Kadınların hepsi gebe kalmadan önce veya gebeliğin erken evresinde VTE'ye ilişkin risk faktörleri açısından belgelenmiş bir değerlendirmeden geçmelidir [11].

DVT'nin tedavisinde akut dönemde (ilk 5-10 gün), subkutan düşük molekül ağrılıklı heparin, subkutan fondaparinuks veya intravenöz fraksiyone olmayan heparin kullanıması önerilmektedir. Hastaya ait özel bir durum söz konusu değilse (tekrarlayan DVT, altta yatan devam eden tetikleyici faktör $\mathrm{vb}$ ) tedavi en az üç ay sürmelidir. Akut olarak başlanan 
Tablo 1. Avrupa toplumunda, gebelerde doğuştan trombofili ve eşlik eden tromboemboli riskinin prevalansı

\begin{tabular}{lll}
\hline Risk faktörü & Prevalansı (\%) \\
\hline Faktor V Leiden mutasyonu & Heterozigot & $2-7$ \\
& Homozigot & $0,2-0,5$ \\
ProtrombinG20210A mutasyonu & Heterozigot & 2 \\
& Homozigot & Nadir \\
Antitrombin eksikliği (etkinlik <\%80) & $<0,1-0,6$ \\
Protein C eksikliği (etkinlik <\%75) & $0,2-0,3$ \\
Protein S eksikliği (etkinlik <\%65) & $<0,1$ \\
\hline
\end{tabular}

*Marik PE, Plante LA. Venous thromboembolic disease and pregnancy. N Engl J Med

tedaviye varfarin ile devam edilebilir. Yeni oral antikoagülan ilaçlar (YOAK) (dabigatran, rivaroksaban, apiksaban, edoksaban) DVT ve PE tedavisinde kullanılmaktadır. YOAK'lar etkinlik bakımından en az varfarin kadar etkili olup majör kanamalar açısından varfarinden daha güvenlidir.

Gebelik ve loğusalık döneminde VTE'nin tedavisi için DMAH tercih edilen ilaçtır. Tedavi edici DMAH dozlarıyla yinelenen VTE riski $\% 1,1$ oranındadır. Bizim vakamızda da DMAH tedavisine rağmen DVT atağı gelişmiştir. Vücut ağırlığına göre hesaplanan tedavi edici dozla (örn: günde iki kez $1 \mathrm{mg} / \mathrm{kg}$ dozda enoksaparin; 100 IU/ kg dozda dalteparin) 4-6 saatlik maksimal anti-Xa değerlerinde 0,6-1,2 IU/mL ulaşılması hedeflenir [12]. VTE hastalarında düzenli aralıklarla anti-XA düzeylerinin izlenmesi gerekliliği tartışmalıdır. Ancak, DMAH'nin kullanıldığı mekanik kapaklı hastalarda bu izlemin gerekli olduğu bilinmektedir. VTE hastalarında ise durum bu kadar açık değildir. DVT olan pospartum vakamızda maksimal antiXa değerlerine ulaşılamadığı için tekrarlayan VTE atakları gelişmiş olabilir. Tedavi için belli bir anti-Xa düzeyini sürdürme amacıyla gebelik ilerledikçe doz artımı gereksinmesi bilindiğine göre, VTE hastalarında gebelik sırasında ve loğusalık da anti-Xa düzeylerinin belirlenmesi uygun bir yaklaşım gibi görünmektedir [13, 14].

Sonuç olarak, tedavi edici dozlarda DMAH alan vakamızda tekrarlayan VTE'nin oluştuğu gerçeği göz önüne alındığında, trombofili hastalarında gebelik ve loğusalık döneminde, tekrarlayan VTE'lerin önlenmesi için anti-Xa düzeylerine göre DMAH doz ayarı yapılması düşünülmelidir. Bu klinik kararın geçerliliği prospektif çalışmalarla doğrulanmalıdır.

Çıkar ilişkisi: Yazarlar çıkar ilişkisi olmadığını beyan eder.

\section{Kaynaklar}

1. Kurz X, Kahn SR, Abenhaim L, et al. Chronic venous disorders of the leg: epidemiology, outcomes, diagnosis and management: summary of an evidence-based report of the VEINES task force. Int Angiol 1999;18:83102. Available at: https://pubmed.ncbi.nlm.nih. gov/10424364 1945260. Accessed February 8, 2021

2. Heit JA, Mohr DN, Silverstein MD, Petterson TM, O'Fallon WM, Melton LJ 3rd. Predictors of recurrence after deep vein thrombosis and pulmonary embolism: a population-based cohort study. Arch Intern Med 2000;160:761-768. https://doi.org/10.1001/ archinte.160.6.761

3. Yamashita $\mathrm{Y}$, Morimoto $\mathrm{T}$, Amano $\mathrm{H}$, et al. Deep vein thrombosis in upper extremities: Clinical characteristics, management strategies and long-term outcomes from the COMMAND VTE Registry. Thrombosis Research 2019;177:1-9. https://doi.org/10.1016/j. thromres.2019.02.029

4. Kucher N. Clinical practice. Deep-vein thrombosis of the upper extremities. N Engl J Med 2011;364:861869. https://doi.org/10.1056/NEJMcp1008740

5. Liu S, Rouleau J, Joseph KS, et al. Epidemiology of pregnancy-associated venous thromboembolism: a population-based study in Canada. J Obstet Gynaecol Can 2009;31:611-620. https://doi.org/10.1016/S17012163(16)34240-2 
6. Heit JA, Kobbervig CE, James AH, Petterson TM, Bailey KR, Melton LJ. Trends in the incidence of venous thromboembolism during pregnancy or postpartum: a 30-year population-based study. Ann Intern Med 2005;143:697-706. https://doi.org/10.7326/0003-4819143-10-200511150-00006

7. O'Connor DJ, Scher LA, Gargiulo NJ, Jang J, Suggs WD, Lipsitz EC. Incidence and characteristics of venous thrombo embolic disease during pregnancy and the postnatal period: a contemporary series. Ann Vasc Surg 2011;25:9-14. https://doi.org/10.1016/j. avsg.2010.04.003

8. Rutherford SE, Phelan JP. Deep venous thrombosis and pulmonary embolism in pregnancy. Obstet Gynecol Clin North Am 1991;18:345-370. Available at: https:// europepmc.org/article/med/1945260. Accessed December 21, 2020

9. Sullivan EA, Ford JB, Chambers G, Slaytor EK. Maternal mortality in Australia, 1973-1996. Aust N Z J Obstet Gynaecol 2004;44:452-457. https://doi.org/10.1111/ j.1479-828X.2004.00313.x

10. Marik PE, Plante LA. Venous thromboembolic disease and pregnancy. N Engl J Med 2008;359:2025-2033. https://doi.org/10.1056/NEJMra0707993

11. Royal College of Obstetricians and Gynaecologists. Reducing the Risk of Thrombosis And Embolism During Pregnancy and the Puerperium. Green-top Guideline No. 37a: 2009. Available at: https://www. rcog.org.uk/globalassets/documents/guidelines/gtg37a.pdf. Accessed December 21, 2020

12. Bates SM, Greer IA, Pabinger I, Sofaer S, Hirsh J. Venous thromboembolism, thrombophilia, antithrombotic therapy, and pregnancy: American College of Chest Physicians Evidence-Based Clinical Practice Guidelines (8th Edition). Chest 2008;133:844886. https://doi.org/10.1378/chest.08-0761
13. Barbour LA, Oja JL, Schultz LK. A prospective trial that demonstrates that dalteparin requirements increase in pregnancy to maintain therapeutic levels of anticoagulation. Am J Obstet Gynecol 2004;191:10241029. https://doi.org/10.1016/j.ajog.2004.05.050

14. Friedrich $E$, Hameed AB. Fluctuations in anti-factor $\mathrm{Xa}$ levels with therapeutic enoxaparin anticoagulation in pregnancy. J Perinatol 2010;30:253-257. https://doi. org/10.1038/jp.2009.164

Hasta onamı: Hastadan yazılı hasta onamı alınmıştır.

\section{Yazarların makaleye olan katkıları}

M.K. vakayı görüp ve klinik değerlendirmesini yapıp, poliklinikte takip etmiştir. M.K. ve M.K.A. vaka ile ilgili verilerin değerlendirmesini yapmışlardır. Olgu sunumunun yazımı M.K. tarafından yapılmış, tüm yazarlar gözden geçirip gerekli düzeltmeleri yapmış ve onaylamıştır. Ayrıca tüm yazarlar olgu sunumunu tartışmış ve son halini onaylamıştır. 